\title{
Kreatifitas Aparatur dalam Mendukung Profesionalisme Pegawai pada Sistem Administrasi Manunggal Satu Atap (SAMSAT) di Kabupaten Pinrang
}

\author{
Akhmad \\ Universitas Pejuang Republik Indonesia (UPRI), Makassar
}

\begin{abstract}
ABSTRAK
Penelitian ini bertujuan untuk mengetahui kreatifitas aparatur dalam mendukung profesionalisme pegawai. Adapun pendekatan yang digunakan adalah deskriptif kuantitatif yang dilaksanakan di Kantor Samsat Pinrang. Teknik pengumpulan data dilakukan dengan cara: 1) wawancara, 2) Kuesioner, 3) dokumentasi, dan 4) Observasi.Teknik analisis data dengan dengan melakukan reduksi, sistematisasi, dan menyatakan pemahaman peneliti secara interpretative dengan menggunakan fasilitas SPSS analisis Multivariate dan Uji Statistik. Kreatifitas dalam peneitian ini mengkajian 2 hal yaitu, 1) pengaturan sistem layanan, penyediaan dokumen-dokumen yang cukup baik, 2) formulir yang lebih jelas dan mudah dipahami oleh masyarakat.
\end{abstract}

Kata Kunci: Kreatifitas, aparatur, profesionalisme pegawai

\begin{abstract}
This study aims to determine the creativity of the apparatus in support of employee professionalism. The approach used is quantitative descriptive implemented in Samsat Pinrang Office. Data collection technique is done by: 1) interview, 2) Questionnaire, 3) documentation, and 4) Observation. Teknik data analysis by by reducing, systematization, and express understanding of researchers by using SPSS Multivariate analysis and statistical test. Creativity in this study studies 2 things namely, 1) the arrangement of the service system, the provision of adequate documents, 2) the form more clear and easily understood by the community.
\end{abstract}

Keywords: Creativity, apparatus, professionalism of employees

\section{PENDAHULUAN}

Peningkatan kemampuan kretifitas seseorang, akan sangat berkenaan dengan pengetahuan dan kecakapan serta keterampilan yang diperoleh melalui pendidikan dan latihan serta pengalaman-pengalaman dalam bekerja (Afrizon, Ratnawulan, \& Fauzi, 2012; Santyasa, 2007; Sumampouw, 2011; Suryaningsih Wardani, 2012). Kemampuan adalah tersedianya modal, kecakapan, ketangkasan, keterampilan atau modal lain yang memungkinkan anggota itu dapat berbuat banyak bagi organisasinya, sedangkan menumbuhkan motivasi merupakan salah satu tantangan berat yang dihadapi organisasi, yakni bagaimana ia dapat menggerakkan para 
pegawainya agar mau dan bersedia mengerahkan kemampuan terbaiknya untuk kepentingan organisasi (Tambingon, 2017). Berhubungan kreatifitas, maka fakta menunjukkan bahwa masih banyak pegawai yang belum cukup baik pengetahuannya dalam mengoperasikan berbagai fasilitas mutakhir, terutama dalam mencetak dokumen-dokumen yang berasal dari prosuk computer.

Banyak pegawai secara teknis memiliki kreatifitas yang tinggi untuk membuat solusisolusi pelayanan yang memadai, namun tidak dapat dijalankan dengan baik, karena aspek motivasional yang ada pada dirinya. Misalnya kebiasaan-kebiasaan memberikan layanan baik. Cepat dan tepat bila mendapat penghargaan atau imbalan yang lebih dari pelanggannya. Dari observasi yang dilakukan menunjukkan bahwa di Kantor Samsat Pinrang, ada kesan bahwa para aparatur yang berada pada bidang-bidang yang menjadi tanggungjawabnya umumnya telah memiliki kemampuan yang memadai dalam memberikan layanan yang diharapkan, bahkan standar-standar dokumen seperti formulir-formulir, telah tersedia dengan baik. Namun pada aspek tertentu. Seperti memberikan layanan yang tepat masih sangat tergantung pada sejauh mana pelanggannya memberikan imbalan yang lebih dari ketentuan yang tertulis.

\section{METODE PENELITIAN}

Penelitian ini menggunakan pendekatan deskriptif kuantitatif (Moleong, 1999). Adapun lokasi penelitian dilaksanakan di Kantor Samsat Pinrang, dengan alas an bahwa kantor ini memiliki kegiatan pelayanan yang penting di masyarakat dan dituntut kinerja sumber daya manusia. Teknik pengumpulan data dilakukan dengan cara: 1) wawancara mendalam dengan melibatkan Kepala UPTD Samsat Pinrang, Kepala Seksi pajak kendaraan, Kepala Seksi Asuransi Jasa Raharja, dan Kepala Seksi Tanda Nomor Kendaraan, 2) Kuesioner, 3) dokumentasi, dan 4) Observasi.Teknik analisis data dengan dengan melakukan reduksi, sistematisasi, dan menyatakan pemahaman peneliti secara interpretative dengan menggunakan fasilitas SPSS analisis Multivariate dan Uji Statistik.

\section{HASIL PENELITIAN PEMBAHASAN}

Peningkatan kemampuan kretifitas seseorang, akan sangat berkenaan dengan pengetahuan dan kecakapan serta keterampilan yang diperoleh melalui pendidikan dan latihan serta pengalaman-pengalaman dalam bekerja. Kemampuan adalah tersedianya modal, kecakapan, ketangkasan, keterampilan atau modal lain yang memungkinkan anggota itu dapat berbuat banyak bagi organisasinya, sedangkan menumbuhkan motivasi merupakan salah satu tantangan berat yang dihadapi organisasi, yakni bagaimana ia dapat menggerakkan para pegawainya agar mau dan bersedia mengerahkan kemampuan terbaiknya untuk kepentingan organisasi. Banyak pegawai secara teknis memiliki kreatifitas yang tinggi untuk membuat solusi-solusi pelayanan yang memadai, namun tidak dapat dijalankan dengan baik, karena aspek motivasional yang ada pada dirinya. Misalnya kebiasaan-kebiasaan memberikan layanan baik. Cepat dan tepat bila mendapat penghargaan atau imbalan yang lebih dari pelanggannya.

Dari observasi yang dilakukan menunjukkan bahwa di Samsat Pinrang, ada kesan bahwa para aparatur yang berada pada bidang-bidang yang menjadi tanggungjawabnya umumnya telah 
memiliki kemampuan yang memadai dalam memberikan layanan yang diharapkan, bahkan standar-standar dokumen seperti formulir-formulir, telah tersedia dengan baik. Namun pada aspek tertentu. Seperti memberikan layanan yang tepat masih sangat tergantung pada sejauh mana pelanggannya memberikan imbalan yang lebih dari ketentuan yang tertulis. Misalnya untuk pelayanan pengesahan pajak kendaraan, yang biayanya telah tercantum di STNK,- namun bila masyarakat hanya bersedia membayar sesuai dengan ketentuan yang berlaku, maka biasanya diselesaikan dalam waktu lebih dari satu hari, sedangkan bila membayar lebih, maka dapat ditunggu.

Pengetahuan seorang aparatur, tentu saja berkaitan dengan pendidikan dan pengalaman kerja mereka selaku aparatur. Pengetahuan berkaitan langsung dengan kecakapan dan komptensi dalam menjalankan tugas-tugasnya selaku aparatur. Seperti telah dikemukakan sebelumnya bahwa dari 27 orang pegawai yang ada di Samsat Pinrang, maka umumnya para pegawai yang ada tersebut memiliki tingkat pendidikan yang memadai, dengan rata-rata berpendidikan S1, bahkan terdapat beberapa orang pegawai dengan kualifikasi pendidikan S2. Bila dilihat dari tingkat pendidikan yang ada, maka pegawai yang ada tersebut seharusnya memiliki daya kreasi yang tinggi dalam menyelesaikan tugas-tugas pokoknya, terutama yang berkaitan dengan aspek layanan kepada masyarakat.

Hasil penelitian menunjukkan bahwa banyak permasalahan-permasalahan yang memang memerlukan kreatifitas kerja dari pegawai itu sendiri, seperti dalam melakukan layanan yang lebih cepat dengan mengatur sistem antrian yang lebih fokus pada kesempatan dan peluang sesuai urutan kehadiran dan kelengkapan dokumen yang dimiliki masyarakat. Bahkan kesediaan petugas layanan untuk memberikan layanan khusus, misalnya meminta kepada warga masyarakat bila mereka tidak dapat menunggu, maka dokumen-dokumen yang diperlukan diambil pada di luar jam kantor, misalnya diantar ke rumah dari pelanggan tersebut.

Penelitian tentang kreatifitas aparatur di Kantor Samsat Pinrang, sebagai salah satu bagian penting dalam menilai profesionalisme aparatur, maka diteliti melalui aspek kecekatan pegawai dalam menyelesaikan tugas-tugas pelayanan kepada masyarakat dan kecermatan dalam pengambilan keputusan.

\section{Cekatan dalam menyelesaikan Tugas}

Kecekatan berhubungan dengan ketangkasan seorang pegawai dalam menyelesaikan tugas pekerjaannya, hal ini berkaitan dengan keterampilan dasar yang dimiliki dalam mengatasi berbagai job order yang diinginkan pelanggannya. Bagi pegawai yang bertugas di Samsat Pinrang, maka aspek kecekatan memang dituntut, sebab cukup banyaknya jenis-jenis layanan yang harus diberikan kepada masyarakat, mulai dari layanan BPKB sampai pada pelayanan pembuatan plat nomor kendaraan. 
$62 \mid$ Jurnal Ad'ministrare: Jurnal Pemikiran Ilmiah dan Pendidikan Administrasi Perkantoran, Vol.4, No.1, 2017

Tabel 1

Tanggapan Responden Terhadap Kecekatan Aparatur Samsat Pinrang

\begin{tabular}{|c|c|c|c|c|c|c|}
\hline No & Pernyataan & $\begin{array}{l}\text { Pilihan } \\
\text { Jawaban }\end{array}$ & Bobot & $\mathrm{F}$ & $\mathrm{f}(\%)$ & $\begin{array}{c}\text { Skor } \\
\text { (Bobot X } \\
\text { F) }\end{array}$ \\
\hline \multirow[t]{6}{*}{1} & \multirow{6}{*}{$\begin{array}{l}\text { Pendapat Responden Mengenai } \\
\text { Keterampilan Aparatur menggunakan } \\
\text { Fasilitas Kerja Mutakhir }\end{array}$} & $\mathrm{a}$ & 5 & 32 & 21.33 & 160 \\
\hline & & $\mathrm{b}$ & 4 & 53 & 35.33 & 212 \\
\hline & & $\mathrm{c}$ & 3 & 35 & 23.33 & 105 \\
\hline & & $\mathrm{d}$ & 2 & 24 & 16.00 & 48 \\
\hline & & $\mathrm{e}$ & 1 & 6 & 4.00 & 6 \\
\hline & & & & 150 & 100.00 & 531 \\
\hline \multirow[t]{6}{*}{2} & \multirow{6}{*}{$\begin{array}{l}\text { Pendapat Responden Mengenai } \\
\text { Kreatifitas Secara Menyeluruh Petugas } \\
\text { Pelayanan }\end{array}$} & $\mathrm{a}$ & 5 & 37 & 24.67 & 185 \\
\hline & & $\mathrm{b}$ & 4 & 56 & 37.33 & 224 \\
\hline & & $\mathrm{c}$ & 3 & 34 & 22.67 & 102 \\
\hline & & $\mathrm{d}$ & 2 & 22 & 14.67 & 44 \\
\hline & & $\mathrm{e}$ & 1 & 1 & 0.67 & 1 \\
\hline & & & & 150 & 100.00 & 556 \\
\hline \multirow[t]{6}{*}{3} & \multirow{6}{*}{$\begin{array}{l}\text { Tanggapan responden mengenai } \\
\text { Kecekatan aparatur dalam menyelesaikan } \\
\text { tugas -tugas pokoknya. }\end{array}$} & $\mathrm{a}$ & 5 & 28 & 18.67 & 140 \\
\hline & & $\mathrm{b}$ & 4 & 58 & 38.67 & 232 \\
\hline & & $\mathrm{c}$ & 3 & 34 & 22.67 & 102 \\
\hline & & $\mathrm{d}$ & 2 & 24 & 16.00 & 48 \\
\hline & & $\mathrm{e}$ & 1 & 6 & 4.00 & 6 \\
\hline & & & & 150 & 100.00 & 528 \\
\hline \multirow[t]{6}{*}{4} & \multirow{6}{*}{$\begin{array}{l}\text { Tanggapan responden mengenai waktu } \\
\text { layanan yang dapat diberikan petugas } \\
\text { layanan }\end{array}$} & $\mathrm{a}$ & 5 & 28 & 18.67 & 140 \\
\hline & & $\mathrm{b}$ & 4 & 34 & 22.67 & 136 \\
\hline & & $\mathrm{c}$ & 3 & 46 & 30.67 & 138 \\
\hline & & $\mathrm{d}$ & 2 & 30 & 20.00 & 60 \\
\hline & & $\mathrm{e}$ & 1 & 12 & 8.00 & 12 \\
\hline & & & & 150 & 100.00 & 486 \\
\hline \multirow[t]{6}{*}{5} & \multirow{6}{*}{$\begin{array}{l}\text { Tanggapan responden mengenai } \\
\text { pernahkah mendapat kesulitan atau } \\
\text { hambatan dalam memenuhi harapan } \\
\text { pelayanan karena alasan tidak ada } \\
\text { operator }\end{array}$} & $\mathrm{a}$ & 5 & 17 & 11.33 & 85 \\
\hline & & $\mathrm{b}$ & 4 & 54 & 36.00 & 216 \\
\hline & & $\mathrm{c}$ & 3 & 67 & 44.67 & 201 \\
\hline & & $\mathrm{d}$ & 2 & 11 & 7.33 & 22 \\
\hline & & $\mathrm{e}$ & 1 & 1 & 0.67 & 1 \\
\hline & & & & 150 & 100.00 & 525 \\
\hline \multicolumn{6}{|c|}{ Total Skor } & 2626 \\
\hline & Nilai Rata-rata Kumulatif & & & 750 & & 3.50 \\
\hline
\end{tabular}

Sumber : Hasil Penelitian, 2013

Tabel 1 tersebut, mengenai jumlah skor total jawaban responden sebesar 2626, untuk nilai tertinggi diberi skor 5. Dari keterangan data tersebut dapat diketahui bahwa 
Akhmad, Kreatifitas aparatur dalam mendukung profesionalisme pegawai pada Samsat di Kabupaten

Pinrang $\mid 63$

penilaian terhadap kecermatan aparatur sebagai indikasi dari profesionalisme dalam pelayanan di Samsat Pinrang sebesar 2626/ 3000X $100=87,53 \%$.

Hasil analisis penelitian di atas tentang deskripsi tingkat kreatifitas aparatur dalam memberikan pelayanan di Samsat Pinrang, maka dari 150 responden yang diteliti diperoleh persentase analisis sebesar $87,53 \%$, yang berarti bahwa menurut responden kereatifitas petugas pelayanan dalam menjalankan tugas-tugas terutama dalam memecahkan masalah-masalah pelayanan adalah tergolong sangat baik. Hasil penelitian observasi yang dilakukan menunjukkan bahwa pelaksanaan tugas-tugas pegawai yang umumnya telah mendapatkan pedoman-pedoman kerja tersendiri secara baku, meskipun sifatnya memang general, sehingga tentu memerlukan keterampilan dalam mengolah dan menata tata kerja mereka, seperti penyiapan dokumen-dokumen yang baku pada jenis-jenis layanan yang paling sering diminta oleh masyarakat.

Jawaban komulatif responden yang menunjukkan sangat baik adalah berarti bahwa menurut pemahaman responden, kreatifitas pegawai yang ditunjukkan melalui kecakapan dan profesionalisme dalam menjalankan tugas adalah dapat dipertanggungjawabkan. Dari 27 orang pegawai yang ada tersebut, umumnya menunjukkan sikap yang cukup mampu menjalankan tugas sesuai dengan harapan pelanggannya, bahkan sebagian dari mereka mudah memberikan solusi layanan dan penjelasan terhadap berbagai urusan yang dimohonkan masyarakat dalam setiap urusan yang berkaitan dengan pelayanan di Samsat Pinrang.

Hasil observasi yang dilakukan bahwa meskipun para pegawai berada pada lingkungan kantor yang tidak megah, namun umumnya mereka menunjukkan sikap profesionalisme, berpakaian yang rapi dengan atribut yang menunjukkan semangat dan gairah kerja yang tinggi. Hal ini pada dasarnya ditunjang oleh posisi selaku pegawai negeri sipil yang memiliki konsep karier yang jelas dan jaminan konpensasi yang jelas pula, sehingga hamper semua aparatur memiliki konsep kepastian terhadap kariernya lebih memadai, sehingga mereka memiliki semangat kerja yang tinggi untuk beraktifitas sesuai harapan masyarakat.

Hasil wawancara dengan salah seorang pegawai senior di Samsat Pinrang, maka diperoleh pernyataan bahwa: “...saya kira para pegawai selaku aparatur Negara yang ada di Kantor ini telah berkosentrasi terhadap kariernya dan tidak lagi berpikir tentang pekerjaan yang lain, sehingga umumnya mereka menunjukkan cara terbaik dalam memberikan pelayanan melalui pelaksanaan tugas pokok dan fungsi dengan sebaikbaiknya. 
64| Jurnal Ad'ministrare: Jurnal Pemikiran Ilmiah dan Pendidikan Administrasi Perkantoran, Vol.4, No.1, 2017

\section{Cermat Mengambil Keputusan}

Cermat berhubungan dengan ketelitian aparatur dalam menyelesaikan tugas-tugas pekerjaan yang ada di Samat Pinrang, ukuran dasarnya adalah kurangnya kesalahan pekerjaan yang diperbuat oleh aparatur.

Tabel 2

Tanggapan Responden Terhadap Kecermatan Aparatur Samsat Pinrang

\begin{tabular}{|c|c|c|c|c|c|c|}
\hline No & Pernyataan & $\begin{array}{l}\text { Pilihan } \\
\text { Jawaban }\end{array}$ & Bobot & $\mathrm{F}$ & $\mathrm{f}(\%)$ & $\begin{array}{c}\text { Skor } \\
\text { (Bobot X } \\
\text { F) }\end{array}$ \\
\hline \multirow{6}{*}{1} & \multirow{6}{*}{$\begin{array}{l}\text { Bagaimana tanggapan anda mengenai } \\
\text { kecermatan pegawai dalam menyelesaikan } \\
\text { tugas-tugasnya }\end{array}$} & $\mathrm{A}$ & 5 & 22 & 14.67 & 110 \\
\hline & & $\mathrm{B}$ & 4 & 42 & 28.00 & 168 \\
\hline & & $\mathrm{C}$ & 3 & 53 & 35.33 & 159 \\
\hline & & $\mathrm{D}$ & 2 & 24 & 16.00 & 48 \\
\hline & & $\mathrm{E}$ & 1 & 9 & 6.00 & 9 \\
\hline & & \multicolumn{2}{|l|}{ Jumlah } & 150 & 100.00 & 494 \\
\hline \multirow{6}{*}{2} & \multirow{6}{*}{$\begin{array}{l}\text { Pernahkah anda mengalami adanya } \\
\text { kesalahan penulisan dalam dokumen yang } \\
\text { anda terima dari layanan di Samsat }\end{array}$} & $\mathrm{A}$ & 5 & 21 & 14.00 & 105 \\
\hline & & B & 4 & 39 & 26.00 & 156 \\
\hline & & $\mathrm{C}$ & 3 & 64 & 42.67 & 192 \\
\hline & & $\mathrm{D}$ & 2 & 22 & 14.67 & 44 \\
\hline & & $\mathrm{E}$ & 1 & 4 & 2.67 & 4 \\
\hline & & \multicolumn{2}{|l|}{ Jumlah } & 150 & 100.00 & 501 \\
\hline \multirow{6}{*}{3} & \multirow{6}{*}{$\begin{array}{l}\text { Menurut pengalaman bapak/ibu, apakah } \\
\text { pernah anda jumpai adanya pegawai yang } \\
\text { harus berulang-ulang mengerjakan sesuatu } \\
\text { karena kesalahan teknis pekerjaan }\end{array}$} & $\mathrm{A}$ & 5 & 20 & 13.33 & 100 \\
\hline & & $\mathrm{B}$ & 4 & 35 & 23.33 & 140 \\
\hline & & $\mathrm{C}$ & 3 & 62 & 41.33 & 186 \\
\hline & & $\mathrm{D}$ & 2 & 27 & 18.00 & 54 \\
\hline & & $E$ & 1 & 6 & 4.00 & 6 \\
\hline & & \multicolumn{2}{|l|}{ Jumlah } & 150 & 100.00 & 486 \\
\hline \multirow{8}{*}{4} & \multirow{6}{*}{$\begin{array}{l}\text { Menurut anda apakah keterlitian dan } \\
\text { kecermatan pegawai sudah memadai }\end{array}$} & A & 5 & 28 & 18.67 & 140 \\
\hline & & $\mathrm{B}$ & 4 & 34 & 22.67 & 136 \\
\hline & & $\mathrm{C}$ & 3 & 46 & 30.67 & 138 \\
\hline & & $\mathrm{D}$ & 2 & 30 & 20.00 & 60 \\
\hline & & $E$ & 1 & 12 & 8.00 & 12 \\
\hline & & \multicolumn{2}{|l|}{ Jumlah } & 150 & 100.00 & 486 \\
\hline & Total Skor & & & & & 1967 \\
\hline & Nilai rata-rata kumulatif & & & 600 & & 3.28 \\
\hline
\end{tabular}

Sumber : Hasil Penelitian, 2013

Dari tabel tersebut jumlah skor total jawaban responden sebesar 1967, untuk nilai tertinggi diberi skor 5.Dari keterangan data tersebut dapat diketahui bahwa penilaian terhadap kecermatan aparatur sebagai indikasi dari profesionalisme dalam pelayanan di Samsat Pinrang 
Akhmad, Kreatifitas aparatur dalam mendukung profesionalisme pegawai pada Samsat di Kabupaten

Pinrang $\mid 65$

sebesar 1967/3000X $100=65,56 \%$. Berdasarkan penelitian di atas, jelas tergambar bahwa para pegawai yang ada di Samsat Pinrang, menurut responden adalah termasuk cermat, dalam arti arti bahwa menurut responden jarang sekali ditemukan adanya kesalahan-kesalahan yang terjadi dalam pemberian layanan, terutama dalam hal penulisan data dan nama dalam dokumendokumen yang diinginkan dalam pelayanan.

Sebagaimana diketahui bahwa salah satu tugas pelayanan Samsat adalah memberikan layanan pembayaran Pajak Kendaraan Bermotor, Balik Nama Kendaraan, mutasi kendaraan dan penerbitan STNK yang memerlukan tingkat ketelitian oleh petugas pelayanan, seperti penulisan nama dan data-data pada dokumen. Kesalahan penulisan nomor mesin STNK tentu memberikan implikasi pada aspek hokum dalam penggunaan dokumen yang bersangkutan.

Pernyataan di atas jelas menunjukkan bahwa kreatifitas aparatur pegawai yang ada di Samsat Pinrang, telah dipengaruhi secara internal dan eksternal dari posisinya selaku pegawai negeri sipil, di mana bahwa pertimbangan karier merupakan hal penting yang mampu mendorong pegawai untuk bertindak sesuai dengan harapan stake holdersnya dan keinginan masyarakat selaku subyek dan obyek service mereka.

Upaya pengembangan kreatifitas pegawai dalam menjalankan tugas-tugas pokoknya, maka telah dilakukan berbagai upaya diantaranya: 1) Pemberian kesempatan kepada pegawai untuk melanjutkan pendidikan kejenjang yang lebih tinggi, terutama dari pendidikan SLTA ke jenjang S1 dan dari jenjang S1 ke S2, 2) Memberikan kesempatan kepada pegawai untuk mengikuti pendidikan dan latihan kepemimpinan pada berbagai jenjang berdasarkan tingkat eselon yang dimilikinya, dan 3) Di samping upaya pengembangan pendidikan akademik, maka para pegawai juga diikutkan dalam berbagai kegiatan-kegiatan yang bertujuan meningkatkan pengetahuan pegawai, seperti mengikutkan pada seminar-seminar yang berkaitan dengan aspek tugasnya, serta melakukan mutasi iternal untuk memperluas wawasn pegawai dalam berbagai bidang kerjanya.

Pengetahuan pada umumnya akan berkaitan dengan tingkat pendidikan seseorang. Pendidikan merupakan salah satu hal yang sangat penting dalam meningkatkan kualitas dan kemampuan seseorang. Semakin tinggi tingkat pendidikan seseorang akan mempengaruhi kemampuan seseorang dalam menguasai suatu pekerjaan. Dalam suatu organisasi, pendidikan menjadi suatu dasar pertimbangan dalam melihat kemampuan seseorang untuk melaksanakan tugas-tugas yang akan diembannya. Oleh sebab itu mengapa suatu organisasi menitikberatkan pendidikan sebagai salah satu sarana dalam pengembangan sumber daya manusia. Bagi sumber daya manusia yang ada di lingkungan Samsat Pinrang, peluang untuk meningkatkan pengetahuannya melalui pendidikan formal, memang cukup terbuka, sebab di samping mendapat perhatian dari atasnnya juga terdapat perguruan tinggi yang dapat menampung mereka untuk melanjutkan pendidikan, bahkan mereka dapat diberikan keringanan atas tugastugas rutin. Keikut sertaan pegawai dalam melanjutkan pendidikan formal, lebih banyak datang dari keinginan sendiri, dalam memperbaiki perkembangan kariernya di masa mendatang. Oleh sebab itu pengaturan soal waktu dan biaya merupakan tanggungjawab masing-masing.

Kompetensi pegawai terhadap tugas-tugas jabatan mereka, sangat berkaitan dengan pengetahuan dan kecakapan mereka, oleh sebab itu umumnya penempatan pegawai dalam bidang pekerjaan tertentu selalu dikaitkan atau disesuaikan dengan kemampuan dan 
pengetahuan mereka, dan salah satu indikatornya adalah disiplin ilmu yang mereka miliki. Pengetahuan seorang aparatur, tentu saja berkaitan dengan pendidikan dan pengalaman kerja mereka selaku aparatur. Pengetahuan berkaitan langsung dengan kecakapan dan komptensi dalam menjalankan tugas-tugasnya selaku aparatur.

Meskipun tingkat pendidikan pegawai yang relatif cukup memadai, namun banyak diantara pegawai yang tidak dapat memaksimalkan kreatifitasnya dalam pelayanan, baik yang berhubungan dengan pelayanan kepada pelanggannya (masyarakat) maupun aspek penyelesaian tugas-tugas internalnya. Hal ini terbukti pada masih sering ditemukannya tugas pekerjaan yang harus ditunda karena adanya sebagian tugas yang tidak dapat dikondisikan dengan baik, seperti karena alasan tidak adanya pimpinan atau karena tidak adanya bagian yang khusus menangani pekerjaan yang dimaksud.

Dalam memberikan pelayanan, maka seharusnya selalu ada solusi kepada masyarakat, dan sejauh mungkin tidak menggunakan kata-kata tidak bisa. Oleh sebab itu tingkat kreatifitas pegawai petugas pelayanan sangat dituntut dalam memberikan jawaban dan alternatif solusi kepada masyarakat. Contoh yang paling konkret, ada bagian tertentu di Samsat selalu kehabisan bahan baku untuk urusan tertentu, sepeti notice pajak, blanko STNK yang justru kadang menghambat layanan, kondisi ini jelas dapat dianggap kurang profesional oleh masyarakat.

Penempatan pegawai dalam suatu jabatan tertentu berdasarkan kompetensi teknis yang dimiliki tentu memberikan ruang yang lebih terarah seluruh sumber daya manusia yang ada untuk membina keterampilannya, baik dalam rangka membentuk karakteristik pribadi sebagai modal pribadi dalam mengembangkan kariernya, juga dimaksudkan agar seluruh kebutuhan terhadap penyelesaian pekerjaannya dapat berjalan sesuai harapan.

Pada dasarnya bahwai pegawai yang memiliki keunggulan tersendiri dalam hal keterampilan teknis dalam pekerjaan juga merupakan suatu bentuk aktualisasi diri yang dapat menunjukkan kelebihan-kelebihan tetentu dalam pekerjaan. Bahkan dengan sendirinya pegawai akan merasakan adanya pemenuhan dalam menyelesaikan pekerjaannya dengan lebih baik, bila didukung oleh keterampilan yang memadai. Kadang ada pegawai yang memang harus seedikit lebih stress bahkan kurang bersemangat bila dihadapkan pada suatu pekerjaan yang secara teknis kurang dikuasainya.

Peran dan eksistensi manusia sebagai salah satu unsur manajemen adalah sangat penting dalam organisasi. Posisinya yang urgen ini menjadikan proporsi perhatian manajemen untuk senantiasa berupaya memenuhi kebutuhan dan keinginan pegawainya. Dalam konteks ini terdapat win-win solution antara pegawai dan organisasi. Disatu sisi pegawai merasa puas bekerja dalam organisasi tersebut, dan disisi lain organisasi merasa diunutngkan dengan kinerja yang dihasilkan oleh pegawainya. Antara organisasi dan pegawai bergerak dan digerakkan dalam sistem keseimbangan ini. Artinya adalah apabila organisasi tidak memperhatikan pegawainya, maka pegawai akan seaunya atau bahkan akan meninggalkan organisasi tersebut. Begitupun sebaliknya, bila pegawai tidak dapat memberikan kontribusi yang diharapkan oleh organisasi, maka organisasi cenderung akan memutuskan hubungan kera dengan pegawai.

Keterlibatan tugas (job Involvement) diartikan sebagai suatu derajat sejauh mana seseorang memihak secara psikologis pada pekerjaannya, berpartisipasi aktif didalamnya, dan menganggap kinerjanya penting bagi harga diri. Oleh karena itu pegawai dengan tingkat 
Akhmad, Kreatifitas aparatur dalam mendukung profesionalisme pegawai pada Samsat di Kabupaten

Pinrang $\mid 67$

keterlibatan kerja yang tinggi tentunya akan memihak pada jenis kerja yang dilakukannya karena sangat peduli dengan jenis kerja tersebut. Dengan demikian terdapat hubungan yang kuat antara tingkat keterlibatan kerja yang tinggi dengan kemangkiran dan turnover. Dengan kata lain semakin tinggi keterlibatan kerja semakin rendah kemangkiran dan turover.

Setiap organisasi memiliki keunikan sendiri-sendiri, baik budaya, tradisi dan metode tindakannya yang secara keseluruhan menciptakan iklimnya, sehingga lingkungan ditempat kerja dipandang sebagai kepribadian organisasi. Bagi Kantor Samsat Pinrang, aspek manajemen dalam arti pengelolaan organisasi sumber daya manusia, dilakukan dengan berpedoman pada mekanisme dan aturan yang jelas, termasuk dalam hal keputusan-keputusan mengenai penempatan pegawai berdasarkan analisis jabatan dan job diskripsi, sehingga pembagian tugas dengan jelas dalam organisasi.

Dari struktur organisasi yang ada, dalam hal manajemen sumber daya manusia pegawai di Samsat Pinrang, maka terjadi suatu penggarisan struktur organisasi berdasarkan peran dan fungsi masing-masing, bahkan dengan cukup jelas dalam penempatan pegawai berdasarkan kemampuan dan keahlian yang dimiliki, jumlah pegawai yang berjumlah 27 pegawai umumnya ditempatkan sesuai dengan kemampuan terutama dilihat dari latar belakang pendidikan yang dimiliki, sehingga memungkinkan para pegawai untuk mengaktualisasikan kreatifitas dan kemampuannya dalam bekerja.

\section{SIMPULAN}

Profesionalisme aparatur dilihat dari tingkat kretifitas kerja sumber daya manusia dalam memberikan pelayanan, maka diperoleh informasi bahwa faktor kreatifitas adalah baik, dalam arti bahwa peluang-peluang untuk menghasilkan layanan yang optimal dengan mengerahkan kreatifitas sumber daya aparatur dalam memberikan layanan. Berbagai indikator yang ada menunjukkan kreatifitas pegawai, diantaranya adalah pengaturan sistem layanan, penyediaan dokumen-dokumen dan formulir yang lebih jelas dan mudah dipahami oleh masyarakat. Bahkan penyediaan dokumen-dokumen dan data dalam bentuk software memberikan indikasi kreartifitas yang memadai dari sumber daya aparatur. Bentuk kreatifitas lain yang sering ditunjukkan adalah kemampuan memberikan penjelasan secara personal kepada warga masyarakat yang sedang mendapatkan pelayanan.

\section{DAFTAR PUSTAKA}

Afrizon, R., Ratnawulan, R., \& Fauzi, A. (2012). Peningkatan Perilaku Berkarakter dan Keterampilan Berpikir Kritis Siswa Kelas IX MTsN Model Padang Pada Mata Pelajaran Ipa-fisika Menggunakan Model Problem Based Instruction. Jurnal Penelitian Pembelajaran Fisika, 1(1).

Moleong, L. J. (1999). Metodologi penelitian. Bandung: PT. Remaja Rosda Karya.

Santyasa, I. W. (2007). Model-model pembelajaran inovatif. Universitas Pendidikan Ganesha.

Sumampouw, H. M. (2011). Keterampilan Metakognitif dan Berpikir Tingkat Tinggi dalam Pembelajaran Genetika (Artikulasi Konsep dan Verifikasi Empiris). Bioedukasi: Jurnal 
68| Jurnal Ad'ministrare: Jurnal Pemikiran Ilmiah dan Pendidikan Administrasi Perkantoran, Vol.4, No.1, 2017

Pendidikan Biologi, 4(2), 23-39.

Suryaningsih Wardani, E. (2012). Pengaruh Kompensasi, Keahlian dan Motivasi Kerja Terhadap Prestasi Kerja Karyawan Pada PT. Pembangkitan Jawa Bali Unit Pembangkitan Muara Tawar.

Tambingon, P. D. Y. G. (2017). Kinerja Pegawai Pada Bagian Humas Sekretariat Daerah Kabupaten Kutai Barat. Jurnal Paradigma (JP), 3(3), 260-270. 